СОВРЕМЕННЫЕ ПРЕДСТАВЛЕНИЯ О СТРУКТУРЕ И МЕХАНИЗМАХ ФУНКЦИОНИРОВАНИЯ

СУКЦИНАТДЕГИДРОГЕНАЗЫ

Магомедова К.М., Арсланова Р.М., Османова П.М., Гаджиева А.К.

Федеральное государственное бюджетное образовательное учреждение высшего образования

«Дагестанский государственный университет»

Направление подготовки «Биология»

Республика Дагестан, г. Махачкала, Россия

\title{
MODERN CONCEPTS OF THE STRUCTURE AND MECHANISMS OF FUNCTIONING OF SUCCINATHYDROGENASE
}

Magomedova K.M., Arslanova R.M., Osmanova P.M., Gadzhieva A.K.

Federal state Budgetary educational institution of Higher Education

«Dagestan state University»

«Biology» program

Makhachkala, Russia

\section{1.Введение}

Сукцинатдегидрогеназа (СДГ и КФ 1.3 .5 .1$)$ представляет собой гетеротетрамерный ферментативный комплекс, который одновременно участвует в цикле Кребса и дыхательной цепи переноса электронов. Фермент 
играет центральную роль в клеточном метаболизме и преобразовании энергии. На шестой стадии цикла Кребса сукцинатдегидрогеназа катализирует реакцию окисления сукцината до фумарата с восстанавлением убихинона до убихинола. СДГ содержит ковалентно связанный кофактор ФАД. Активность фермента выявлена практически во всех исследованных организмах. Даже некоторые анаэробные прокариоты содержат множественные гены, кодирующие II комплекс дыхательной цепи. Впервые очищенный препарат растворимой СДГ из животных тканей был получен Сингером в 1954 г. [1].

В исследовании сукцинатдегидрогеназы важную роль играет выяснение механизмов регуляции активности СДГ не только на уровне белковой молекулы (воздействие на скорость ее функционирования различных метаболитов), но и регуляция фермента путем действия на генетический аппарат. Известно, что комплекс СДГ связан с внутренней мембраной митохондрий, имеет сложную структуру и состоит из 4 субъединиц, включая 2 гидрофильные субъединицы - СДГ-А и СДГ-Б, которые вместе образуют каталитический центр энзима, и 2 гидрофобные субъединицы - СДГ-С и СДГ-Д [2].

СДГ - это мультисубъединичный фермент, для правильной сборки которого требуется ряд белков в несколько этапов. Этот фермент имеет медицинское значение, так как существует широкий спектр заболеваний человека от рака до нейродегенерации, связанной с неисправностью СДГ. Некоторые из этих нарушений недавно были связаны с дефектными факторами сборки, что стимулирует дальнейшие исследования в этой области. Кроме того, этот фермент имеет сельскохозяйственное значение, так как было разработано множество фунгицидов, предназначенных специально для этого фермента в растительных грибковых патогенах.

Субъединицы СДГ кодируются четырьмя генами - СДГА, СДГБ, СДГС, СДГД. СДГ является единственным комплексом окислительного фосфорилирования, в котором отсутствуют субъединицы, кодируемые 
митохондриальным геномом. Исследование субъединичного строения фермента, физико-химических свойств, кинетики катализируемой реакции невозможно без получения ферментных препаратов, характеризующихся гомогенностью [3].

\section{2.Сукцинатдегидрогеназа: структура, механизм катализа, регуляция активности}

\section{1.Структура сукцинатдегидрогеназы}

СДГ состоит из четырёх субъединиц, кодируемых ядерным геномом. Молекулярная масса составляет от 125кД до 140 кД. СДГ-С и СДГ-Д содержат гидрофобные компоненты, которые закрепляют комплекс на внутренней мембране митохондрий. Гидрофобные субъединицы С и Дтрансмембранные белки. Вместе они образуют цитохром b560, в шести трансмембранных $\alpha$-спиралях которого расположен гем b и сайт связывания убихинона. Две молекулы фосфолипидов, один кардиолипин и один фосфатидилэтаноламин, которые заполняют гидрофобное пространство между субъединицами С и Д ниже гема b [2]. В сторону матрикса обращены субъединицы СДГ-А и СДГ-Б. Субъединица СДГ-А содержит ковалентно связанный ФАД и сайт для связыввания сукцината, а субъединица СДГ-Б содержит 3 железо-серных кластера: [2Fe-2S], [4Fe-4S] и [3Fe-4S], которые обеспечивают перенос электрона от сукцината к убихинону. В комплексе СДГ есть два убихинон-связывающих сайта. Сайт с высоким сродством образован субъединицами СДГ-Б, СДГ-С и СДГ-Д, расположенными вблизи со стороны матрицы внутренней митохондриальной мембраны. Сайт с низким сродством образован субъединицами СДГ-С и СДГ-Д, расположенными ближе к межмембранному пространству внутренней митохондриальной мембраны. Наконец, гем В, который расположен между СДГ-С и СДГ-Д, предположительно поглощает свободные электроны, чтобы предотвратить образование активных форм кислорода [4]. 
На субъединице А расположен сайт связывания и окисления сукцината. Сайт связывания сукцината и сайт связывания убихинона соединены цепочкой из редокс-центров, состоящей из ФАД и трёх железосерных кластеров. Эта цепочка простирается на $40 \AA$ через всё тело фермента. Приблизительная дистанция между кофакторами не превышает физиологический предел для переноса электронов в $14 \AA$ [2].

Установлено, что присутствие в структуре комплекса II всех субъединиц является необходимым требованием для обеспечения его стабильности. Исследования на дрожжах показали, что отсутствие одной из гидрофобных субъединиц СДГ приводит к значительному снижению обеих гидрофильных субъединиц, следовательно, каталитический центр, не может существовать как свободная димерная структура, без мембранного домена [5].

Все больше свидетельств указывает на то, что дыхательный комплекс II является источником и модулятором активных форм кислорода (АФК). Как потеря функций II комплекса, так и его фармакологическое ингибирование могут приводить к образованию активных форм кислорода в клетках, что оказывает существенное влияние на развитие патофизиологических состояний, то есть рака и нейродегенеративных заболеваний. Несмотря на то, что участие II комплекса в производстве АФК была определена, тонкие детали все еще ожидают прояснения. Важно разрешить эти аспекты, чтобы полностью понять роль II комплекса в патологии и изучить его терапевтический потенциал при раке и других заболеваниях [6].

\section{2. Механизм катализа сукцинатдегидрогеназы}

Сукцинатдегидрогеназа является ключевым ферментом в промежуточном метаболизме и преобразовании энергии в живых клетках. Митохондриальный комплекс СДГ катализирует окисление сукцината до фумарата в цикле Кребса и подает электроны в пул убихинона (UQ) 
дыхательной цепи (рис.1.). Этот фермент катализирует окисление сукцината до фумарата в цикле Кребса (1), а полученные электроны поступают в дыхательный комплекс III для восстановления кислорода и образования воды (2). Это создает электрохимический градиент через внутреннюю мембрану митохондрий, что позволяет синтезировать АТФ. Альтернативно, электроны могут быть направлены для уменьшения пула убихинона (пула UQ) и обеспечения восстанавливающих эквивалентов, необходимых для уменьшения супероксидных анионов, происходящих либо из экзогенного источника, либо из самой дыхательной цепи (3) [7].

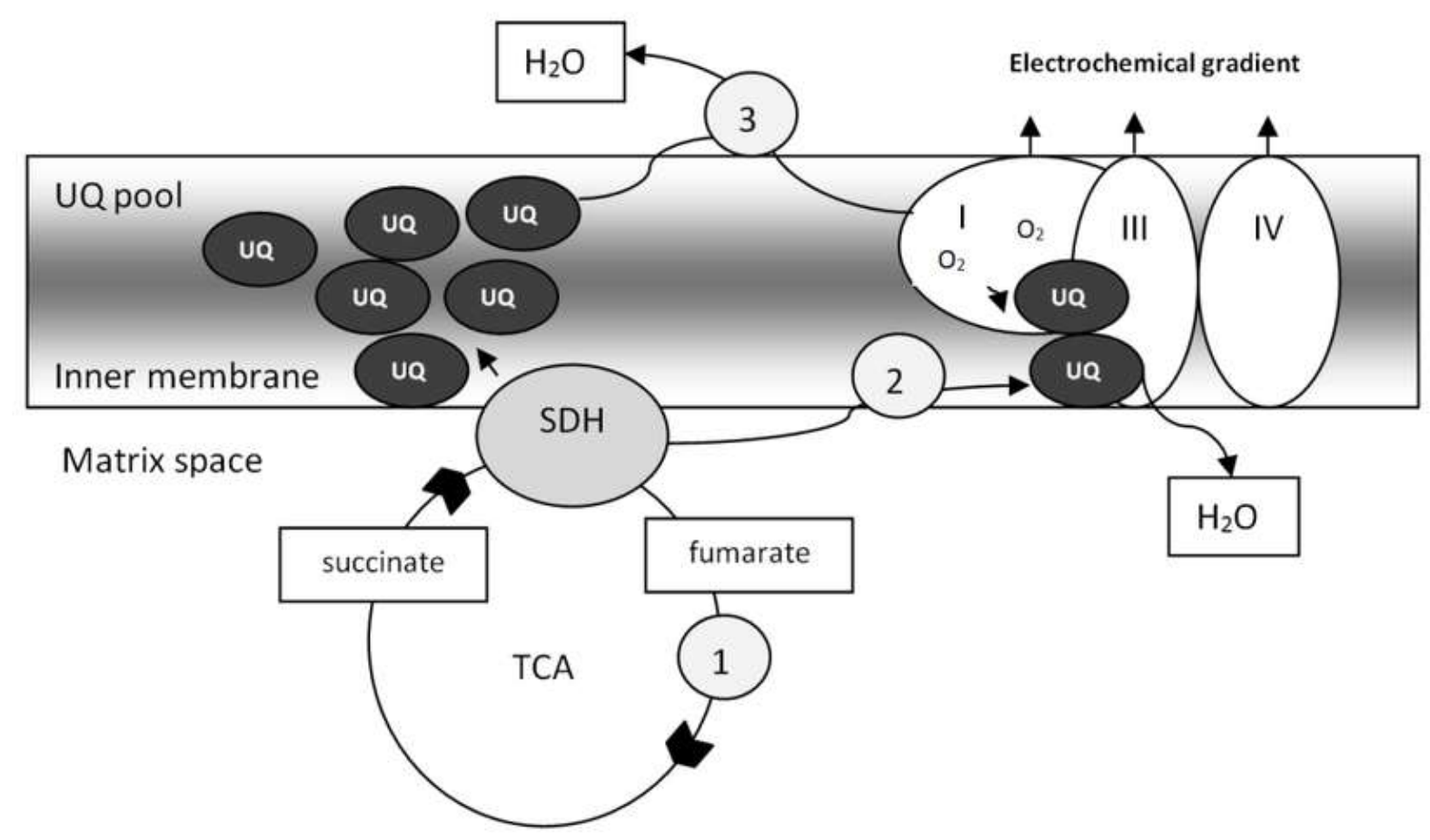

Рисунок 1. Подача электронов в пул убихинона дыхательной цепи. [7].

В реакции окисления сукцината до фумарата два атома водорода удаляются из субстрата с помощью ФАД, протезной группы, которая тесно связана с сукцинатдегидрогеназой.

Два электрона из восстановленного комплекса СДГ-ФАДН2 переносятся на убихинон (Q). Затем убихинон восстанавливается до убихинола (QH2). Восстановленный убихинол окисляется комплексом III, a затем электроны переносятся через цитохром с в комплекс IV, где молеку- 
лярный кислород восстанавливается до воды. Протонная накачка комплексами I, III и IV генерирует электрохимический градиент, который затем используется для синтеза АТФ комплексом V (АТФ-синтаза).

Биохимические исследования выявили, что в СДГ митохондрий эукариот имеется два сайта связывания убихинона [8]. Первый сайт проксимальный (Qp) располагается на стороне матрицы митохондрий, обладает высоким сродством к убихинону и образован фрагментами СДГБ, СДГС и СДГД, а второй - дистальный (Qd) близок к межмембранному пространству, имеет слабое сродство к убихинону [2,9]. Восстановление убихинона протекает в два этапа: на первом происходит неполное восстановление семихинона (в качестве стабилизатора выступает проксимальный сайт) который восстанавливается до убихинола [2]. В реакции окисления сукцината до фумарата два атома водорода удаляются из субстрата флавинадениндинуклеотидом, протеиновой группой, прикрепленной к сукцинатдегидрогеназе. Два электрона из восстановленного комплекса СДГ ФАДН2 затем переносятся на убихинон растворимой части фермента электронно-транспортной системы. Происходит восстановление убихинона до убихинола. ФАД является неотъемлемым кофактором сукцинатдегидрогеназы. АТФ в митохондриях связывается с окисленным НАДН и ФАДН2 и восстановленным кислородом в воде дыхательной цепи митохондрий [10].

Важным аспектом окисления сукцината комплексом II является требование ковалентно связать ФАД с атомом N-гистидинового остатка через $8 \alpha-\mathrm{N}$ (3) -гистидила, что увеличивает потенциал восстановления кофактора примерно на 150 мВ (от -199 мB до -55 мB в E.coli). Данная связь наблюдается только у сложных членов семейства II, a не в гомологиях растворимых флавопротеином. Механизм ковалентного сближения и прикрепления ФАД к белку не был очерчен, но введение ФАД может облегчаться сложным комплексом II сборным фактором, обозначенным СДГ5 у дрожжей [7] и СДГЕ у бактерий [11]. 
Транспортирование электронов от центра связывания сукцината с первым или проксимальным хинонсвязывающим сайтом осуществляется вдоль цепи окислительно-восстановительных групп, которые включают ковалентно присоединенные ФАД и три кластера железо-серы [12].

В комплексе II расположены два различных активных центра и координированный катализ на этих участках связывает два ключевых биологических пути, то есть окисление сукцината в цикле трикарбоновых кислот и восстановление хинона в цепи переноса электронов. Субъединица СДГА содержит ковалентно присоединенный ФАД-редокс-фрагмент и сайт связывания дикарбоксилата, где сукцинат окисляется до фумарата. Протоны этого окисления переносятся на растворитель, а фумарат действует как следующий субстрат в цикле Кребса. Электроны продукта катализа переносятся на $40 \AA$ через три кластера железо-серы в белке СДГБ. Эти электроны действуют как сосубстраты на втором активном центре, расположенном на границе интегральных мембранных субъединиц. На этом хинон-восстанавливающем сайте, $2 \mathrm{H}+$ и 2е- уменьшают убихинон до убихинола. Полученный пул хинола поддерживает синтез АТФ [13].

Два электрона, абстрагированные от дегидрирования сукцината, последовательно направляются в цепь переноса электронов от флавинадениндинуклеотида до захваченного мембраной убихинона через кофакторы [2Fe-2S], [4Fe-4S], [3Fe-4S] и, возможно, гем b. Этот дальний, линейнолинейный электронный канал простирается более чем на $40 \AA$ от растворимого каталитического домена СДГ до мембранно-закрепляющего домена фермента [2]. Участие гема b как части цепи переноса электронов не было четко установлено, поэтому функциональная значимость гема неясна [14].

\section{3.Регуляция активности фермента сукцинатдегидрогеназы}

Активность СДГ можно модулировать с помощью конкурентов сукцината, ингибиторов убихинона или посттрансляционных модификаций. 
Конкурентными ингибиторами сукцината являются малонат, малат и оксалоацетат. По структуре эти соединения похожи на сукцинат, что объясняет их способность конкурировать за связывание с активным центром СДГ. Примечательно, что как малат, так и оксалоацетат являются метаболитами цикла трикарбоновых кислот. Карбоксин и теноилтрифторацетон являются синтетическими ингибиторами убихинона, которые блокируют перенос электрона от комплекса СДГ к убихинону [4].

Что касается посттрансляционных модификаций, было показано, что фосфорилирование и ацетилирование остатков лизина субъединицы СДГА модулируют активность СДГ [15,16]. Например, снижение SIRT3, обладающий деацетилазной активностью, приводил к накоплению ацетилированного лизина СДГА. Это снизило активность комплекса СДГ. После повторной экспрессии SIRT3 ацетилирование лизина СДГА было удалено, а активность СДГ восстановлена [16]. Точно так же фосфорилирование остатков лизина СДГА оказывает аналогичное влияние на активность СДГ [15]. Недавно сообщалось о сукцинилировании остатков лизина СДГА в клетках, обработанным ингибитором СДГ или при снижение активности сукцинил-КоА-синтетазы. Модификация сукциниллизина может модулировать активность СДГ. [17,18]

Установлено, что в условиях in vitro ингибирующим эффектом на сукцинатдегидрогеназную активность митохондрий обладают все исследованные производные 1,3,4-тиадиазинов. Максимальное ингибирующее влияние показано для L-9 и L-10 1,3,4-тиадиазиновых соединений, под воздействием которых активность СДГ снизилась в 6 раз по сравнению с нативными митохондриями. Высказано предположение о том, что сходный ингибирующий эффект на активность СДГ обусловлен наличием 1,3,4тиадиазиновых колец и колец морфолина, тогда как разная степень ингибирующей активности СДГ, вероятно, связана с различием заместителей в пятом положении 1,3,4-тиадиазинового кольца [19]. 


\section{Заключение}

За последние несколько лет комплекс СДГ стал предметом нового интереса. Это было обусловлено, прежде всего, открытием его роли в различных заболеваниях, а также открытием новых факторов сборки. Как и большинство важных открытий, эти новые открытия дают больше вопросов, чем ответов. Предстоящие годы, вероятно, станут свидетелями нового понимания сборки СДГ, включая новые факторы и большую ясность в отношении механизмов [20].

Таким образом, изучая заболевания человека, связанных с СДГ, позволяет предположить, что фермент играет не только центральную роль в цикле Кребса и дыхательной цепи, но также отличается от других митохондриальных дегидрогеназ благодаря своим уникальным окислительно-восстановительным свойствам. В партнерстве с убихиноном СДГ будет представлять собой важный антиоксидантный фермент в митохондриях [7].

\section{Список литературы}

1. Епринцев, А. Т. Сукцинатдегидрогеназа высших растений / А. Т. Епринцев, В. Н. Попов, Д. Н. Федорин //Воронеж: Центр. черн. книжное изд-во. $-2010 .-184$ с.

2. Yankovskaya, V. Architecture of succinate dehydrogenase and reactive oxygen species generation / V. Yankovskaya, R. Horsefield, S. Törnroth, C. Luna-Chavez, H. Miyoshi, C. Léger, B. Byrne, G. Cecchini, S. Iwata // Science. - 2003. - V.299. P. - 700-704.

3. Епринцев, А.Т. Физико-химические и каталитические свойства сукцинатдегидрогеназы из печени крыс./Епринцев А.Т., Али С. Махмуд//Прикладная биохимия и микробиология. - 2012. - Т.48. C.600-605. 
4. Yeng F.H. Succinate Dehydrogenase Loss in Familial Paraganglioma:Biochemistry, Genetics, and Epigenetics/Yeng F. H.,Maher L. J./ International Journal of Endocrinology. - 2015. - V.2015. - P.3-4.

5. Hao, H.X. SDH5, a gene required for flavination of succinate dehydrogenase, is mutated in paraganglioma / H. X. Hao, O. Khalimonchuk, M.Schraders, N. Dephoure, J. Bayley, H. Kunst, P. Devilee, C. Cremers, J. Schiffman, B. Bentz, S. Gygi, D. Winge, H. Kremer, J. Rutter //J. Science. - 2009. - V. 325 (5944). - P.1139-1142.

6. Kraus, M. Mitochondrial complex II and reactive oxygen species in disease and therapy./ Hadrava Vanova K., Kraus M., Neuzil J., Rohlena J.// J. Redox Report. - 2020. - V.25. - P.-26.

7. Rustin, P. Succinate dehydrogenase and human diseases: new insights into a well-known enzyme./ Rustin P., Munnich A., Rötig A./ Eur. J. Hum Genet. -2002.- V.10. - P.290.

8. Hagerhall, C. Succinate: quinone oxidoreductases. Variations on a conserved theme / C. Hagerhall // Biochimica et Biophysica Acta. - 1997. V. 1320. P. 107-141.

9. Sun, F. Crystal structure of mitochondrial respiratory membrane protein complex 11 / F. Sun, X. Huo, Y. Thai, A. Wang, J. Xu, D. Su, M. Bartlam, Z. Rao // Cell. - 2005. - V.121. - P.1043-1057.

10. Robinson, K.M., Lemire, B.D. Covalent attachment of FAD to the yeast suc-cinate dehydrogenase flavoprotein requires import into mitochondria, prese-quence removal, and folding / K.M. Robinson, BD. Lemire // J. Biol. Chem. - 1996. - V. 271. P.

11. McNeil, M.B. FineranSdhE is a conserved protein required for flavinylation of succinate dehydrogenase in bacteria / M.B. McNeil, J.S. Clulow, N.M. Wilf, G.P. Salmond, P.C // J. Biol. Chem. - 2012. - V. 287. P. 18418-18428. 
12. Lemire B.D, Oyedotun K.S. The Saccharomyces cerevisiae mitochondrial succinate:ubiquinone oxidoreductase / Lemire B.D, Oyedotun K.S. // Biochim Biophys Acta. - 2002. - 1553(1-2):102-16.

13. Iverson, T. Structural Basis for Malfunction in Complex II / Iverson, T, E.Maklashina, G. Cecchini // J Biol Chem. - 2012. - V.287(42). - P.3543035438.

14. Hyung J. Kim. Structure, function, and assembly of heme centers in mitochondrial respiratory complexes / Hyung J. Kim, Khalimonchuk, O, Smith, P., Dennis, R. // Biochim Biophys Acta. - 2012. - V.1823(9). P.1604-1616.

15. Tomitsuka, E., Kita, K., Esumi, H. Regulation of succinate-ubiquinone reductase and fumarate reductase activities in human complex Il by phosphorylation of its flavoprotein subunit / E. Tomitsuka, K. Kita, H. Esumi // J. Proc. Jpn. Acad. - 2009. V. 85. - P. 258-265.

16. Cimen, H. "Regulation of succinate dehydrogenase activity by SIRT3 in mammalian mitochondria,"/ H. Cimen, M.-J. Han, Y. Yang, Q. Tong, H. Koc, and E. C. Koc./J. Biochemistry, vol. 49, no. 2, pp. 304-311, 2010.

17. Park, J. "SIRT5-mediated lysine desuccinylation impacts diverse metabolic pathways,"/ J. Park, Y. Chen, D. X. Tishkoff et al. / J. Molecular Cell. 2013. - V. 50. - N. 6. - P. 919-930.

18. Weinert, B. T. "Lysine succinylation is a frequently occurring modification in prokaryotes and eukaryotes and extensively overlaps with acetylation,"/ B. T. Weinert, C. Schölz, S. A. Wagner et al. / J. Cell Reports, vol. 4, no. 4, pp. 842-851, 2013.

19. Вахнина, Н.А. Изменение активности сукцинатдегидрогеназы митохондрий печени под воздействием класса соединений 1,3,4-тиадиазина / Н.Ж. Вахнина, Н.А. Алисултанова, В.Д. Щадрина Е.Р., Бойко, Л.Б., Сидорова.// В мире научных открытий. - 2014. - №2. - С.44-55. 
20. Rutter, J. Succinate dehydrogenase - Assembly, regulation and role in human disease./ J. Rutter, D. R.Winge, J. D. Schiffmancd/ J. Mitochondrion. - 2010. - V.10. - P.415. 